\title{
The dynamics of knowledge about stemflow: a systematic review
}

A dinâmica do conhecimento sobre o escoamento pelo tronco: uma revisão sistemática

Kelly Cristina Tonello ${ }^{\circledR}$, Alexandra Guidelli Rosa ${ }^{2}\left(\mathbb{0}\right.$, José Augusto Salim ${ }^{3}\left(\mathbb{C}\right.$, Carina Julia Pensa Correa ${ }^{4}(\mathbb{0}$, Marcelle Teodoro Lima ${ }^{4}$ (1)

\section{A B S T R A C T}

The importance of stemflow to hydrology and biogeochemistry in forest ecosystems is highlighted by the growing interest of the scientific community since the 1970s. This paper summarizes the main contributions of stemflow (SF) studies from recent years through a systematic review of the literature, including 375 scientific articles published between 2006 and 2019. Shrub SF has shown superior efficiency $(11.1 \%)$ compared to tree species (3.6\%). Branches, bark texture and composition, branch and leaf saturation capacity, and wind intensity were identified as factors that significantly influence SF. However, despite the increasing number of publications on the subject, most of them focus on semiarid regions of Asia, particularly of China, and temperate regions. Thus, there is still a lack of knowledge about the role of the different species in the biogeochemical cycle concerning the SF in tropical and semi-equatorial regions.

Keywords: forest hydrology; forest restoration; rainfall repartitioning; throughfall; biogeochemical cycle.

\section{RE S U M 0}

A importância do escoamento pelo tronco para a hidrologia e biogeoquímica dos ecossistemas florestais é destacada pelo crescente interesse da comunidade científica desde os anos 1970. Para resumir as principais contribuições dos estudos de escoamento pelo tronco (Sf) dos últimos anos, este trabalho apresenta uma revisão sistemática da literatura, incluindo 375 publicações científicas de 2006 e 2019. O Sf em arbustos demonstrou uma eficiência superior $(11,1 \%)$ ao escoamento pelo tronco em espécies arbóreas (3,6\%). Galhos, textura e composição das cascas, capacidade de saturação das folhas e intensidade dos ventos foram identificados como os fatores que mais influenciam o Sf. No entanto, apesar do crescente número de publicações sobre o tema, a maioria concentra-se em regiões semiáridas da Ásia, principalmente na China e em regiões temperadas. Assim, para as regiões tropical e semiequatorial, ainda há um desconhecimento sobre o papel das diferentes espécies no ciclo biogeoquímico em relação ao Sf.

Palavras-chave: hidrologia florestal; restauração florestal; reparticionamento de chuvas; precipitação interna; ciclo biogeoquímico.

\footnotetext{
${ }^{1}$ Professor and leader of the research group on Hydrology in Forest Ecosystems (Hidrologia em Ecossistemas Florestais - Hidrolef), Universidade Federal de São Carlos (UFSCar) - São Carlos (SP), Brazil.

${ }^{2}$ Master's student from the Graduate Program in Planning and Use of Renewable Resources (Programa de Pós-Graduação em Planejamento e Uso de Recursos Renováveis - PPGPur), UFSCar - São Carlos (SP), Brazil.

${ }^{3}$ Computer Engineer, UFSCar - São Carlos (SP), Brazil.

${ }^{4} \mathrm{PhD}$ student from the PPGPur, UFSCar - São Carlos (SP), Brazil.

Correspondence address: Kelly Cristina Tonello - Rodovia João Leme dos Santos, km 110 - Itinga - CEP: 18052-780 - Sorocaba (SP), Brazil E-mail: kellytonello@ufscar.br

Conflicts of interest: the authors declare that there are no conflicts of interest.

Funding: International Paper Co., Universidade Federal de São Carlos and Conselho Nacional de Desenvolvimento Científico e Tecnológico (CNPq).

Received on: 01/16/2020. Accepted on: 04/22/2020.
}

https://doi.org/10.5327/Z2176-947820200675 


\section{Introduction}

Research related to forest restoration stimulates reforestation involving predominantly exotic tree species, plantings with a high diversity of regional native forests (GALETTI et al., 2018), and other ways of catalyzing the regeneration potential of the area to be restored. This knowledge is increasing due to the demand for the environmental regularization of productive activities and the mitigation of several environmental impacts (RODRIGUES; BRANCALION; ISERNHAGEN, 2009).

Ecological restoration is defined as the science, practice, and art of assisting and managing the restoration of the ecological integrity of ecosystems. This process includes a minimum level of biodiversity and variability in the structure and functioning of ecological processes, considering their ecological, social, economic, and environmental values (SOCIETY FOR ECOLOGICAL RESTORATION INTERNATIONAL, 2004). According to Rodrigues, Brancalion and Isernhagen (2009), this definition brings an ecosystem perspective of the ecological restoration process. However, a practical approach is still a huge challenge due to the high complexity of biological interactions between species and the relationships of species with abiotic factors in the environment. This fact highlights the lack of knowledge about the complex interactions that regulate the functioning of these ecosystems. Another major challenge is choosing between the different assessments and monitoring models required for the same type of ecosystem (BRANCALION et al., 2012).

Some initiatives seek to establish standardized parameters and models for monitoring biodiversity and ecosystems, allowing comparisons between studies and simplifying the decision-making process regarding environmental conservation, preservation, and recovery. Brancalion et al. (2012) point out that the universe of indicators

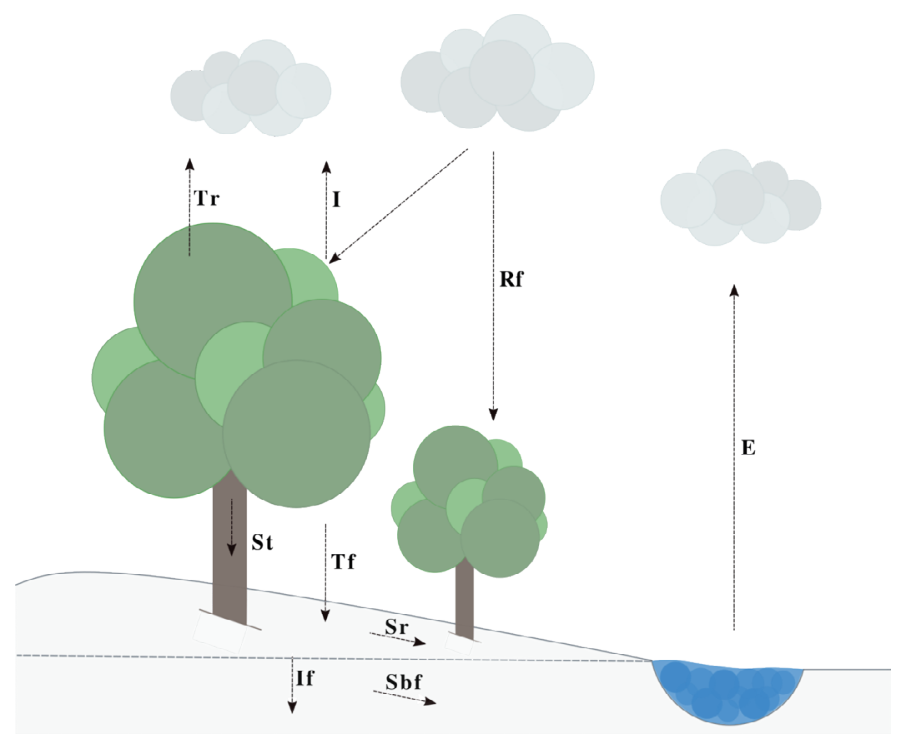

Figure 1 - Schematic representation of the hydrological cycle.

Rf: rainfall; Tf: throughfall; I: interception; Tr: transpiration; E: evaporation; Sf: stemflow; If: infiltration; Sr: surface runoff; Sbf: subsurface flow. that can be evaluated is excessively extensive, such as the richness, diversity, and density of native species, biological invasion, rainfall, seed bank, phenology of plant species, genetic diversity of seedlings used, ecosystem services, gene flow, plant-animal interaction, and many other possibilities.

Understanding the role of forests in the hydrological cycle is fundamental to forest management practices related to hydrological and watershed conservation. Figure 1 presents the schematic representation of the hydrological cycle in the natural environment. Forest cover is one of the main responsible for the variation of the hydrological cycle in the different regions of the world. It interferes with water dynamics at various stages of the system, including transfers to the atmosphere and rivers. Some authors even report the importance of humidity and precipitation for the occurrence of certain forest and epiphytic species in riparian forests (ROCHA-URIARTT et al., 2015). Others underline the necessity of analyzing precipitating weather systems, as well as the seasonal rainfall variation and its influence on the variability of litterfall production in the mangrove forest, for example (SOUZA et al., 2019).

One of the main forest influences is the damping, direction, and retention of rainwater by the tree canopy, a process called interception. This retained water becomes available for evaporation. The remainder reaches the ground as throughfall and stemflow. Consequently, the water table supply is favored, and the flow variation throughout the year decreases, besides delaying the flood peaks (OLIVEIRA JÚNIOR; DIAS, 2005).

Stemflow can be defined as the intercepted rainwater collected by the stem that passively descends to the roots through gravity (BIDDICK; HUTTON; BURNS, 2018; BESSI et al., 2018a; BESSI et al., $2018 \mathrm{~b}$ ) and has been recognized as an essential process of water supply to spatially located areas of forest soil (TANAKA et al., 2017). According to Levia and Germer (2015), many researchers recognize stemflow as an important phenomenon that can have considerable effects on ecosystem hydrology, biogeochemistry, and ecology. Throughfall and stemflow are processes responsible for precipitation and solute transfer from a vegetative canopy to the soil (LEVIA et al., 2013).

However, despite representing a small proportion of gross rainfall, stemflow is an essential and poorly studied water flow in forested areas (CAYUELA et al., 2018). Recent studies have highlighted its complexity and relative importance in understanding soil and groundwater recharge (SPENCER; VAN MEERVELD, 2016; MCKEE; CARLYLE-MOSES, 2017; MICHALZIK et al., 2016).

Thus, this paper aims to summarize the main contributions of stemflow studies through a systematic review of the last 15 years, including country distribution, vegetation type, stemflow efficiency, research importance, and perspectives.

\section{Materials and Methods}

significant advances have been made in several related areas, such as ground-flow interactions, the effects of lichens and other epiphytes, and a deeper understanding of the influence of climate on stemflow (LE- 
VIA; GERMER, 2015). Notably, the increase in the breadth and diversity of stemflow publications and the confirmation of its importance to the hydrology and biogeochemistry of wooded ecosystems is perceived by the growing interest of the scientific community since the 1970s. This assumption could be verified by the frequency of the term "stemflow" in scientific works indexed by the Scopus portal (ELSEVIER BV, 2019) (Figure 2).

However, the full understanding of the importance and influence of stemflow for plant species, soil dynamics, and the biogeochemical cycle still requires many further studies. We performed this systematic literature review to outline the area and identify general patterns and knowledge gaps in the role of stemflow. To that end, we used the databases of scientific publications Scopus and SciELO (SCIELO, 2019).

Both bases were searched for scientific articles with the terms "stemflow" and "throughfall" in the keyword field. The search was limited to return only documents in English, Portuguese, and Spanish. Also, results were restricted to works published after 2006. The SciELO database search was also limited to only scientific articles from Brazilian collections (Table 1). A total of 375 papers were retrieved - 357 from Scopus and 18 from SciELO.

The recovered works were screened considering the following criteria: studies that investigated stemflow in agricultural plants (e.g., sugar cane, coffee, soybean, corn) are excluded; works that directly measured stemflow using a flow pickup ring (e.g., works that used the soil moisture near the trunk for indirect flow measurement) are excluded; works limited to the study of flow and concentration of pollutants, pesticides, and other anthropogenic aerosols are excluded; mathematical modeling works and stemflow simulations are excluded; only works that could be fully retrieved are included.

This first selection of articles resulted in a total of 124 papers, and studies that investigated the concentration of radioactive isotopes in forest areas near Fukushima after the nuclear disaster and works related to the concentration of pollutants (e.g., metals) and pesticides were excluded. The selected articles were thoroughly analyzed, and the extracted data are available online (GUIDELLI, 2019). We carried out the subsequent analyses with the aid of the R statistical software (R CORE TEAM, 2018), as well as the elaboration of the graphs. Geospatial analysis and graphing were performed using the R: rgeos (BIVAND; RUNDEL, 2018) and raster (HIJMANS, 2018) packages.

\section{Results and Discussion}

The analysis of the selected studies reveals that the proportion of stemflow concerning the total precipitation averages $4.7 \%$. However, the variance of these data is high (35.6), indicating that several factors are acting together to determine runoff (e.g., rainfall intensity and

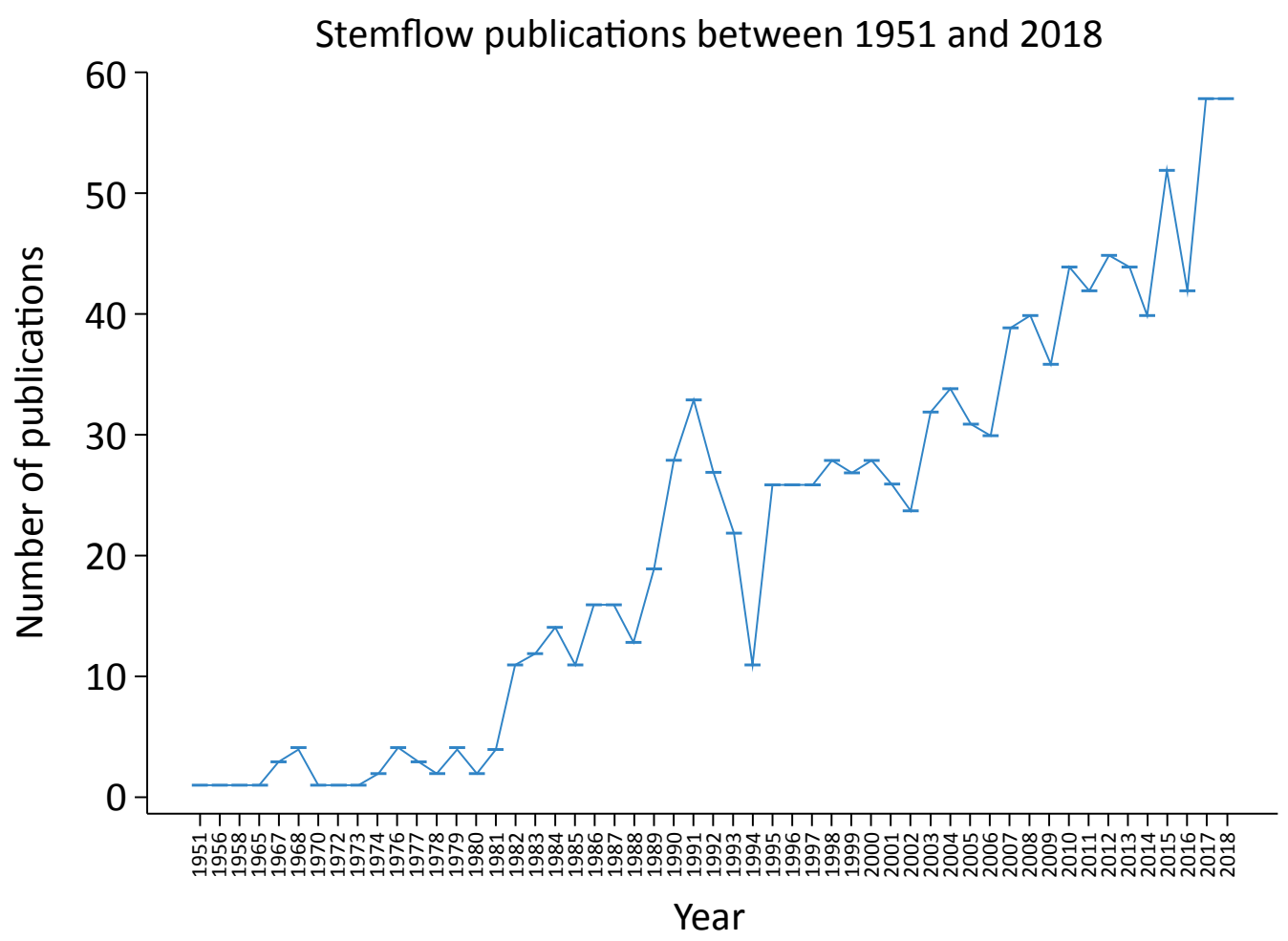

Figure 2 - Frequency of occurrence of the term "stemflow" in scientific publications between 1951 and 2018, according to Scopus (1,146 documents).

Source: Elsevier BV (2019). 
amount, species morphological characteristics, wind direction, climate factors, biotic interactions). A survey of 124 studies reveals that, in approximately $70 \%$ of the observations, stemflow in different regions of the planet represents less than $5 \%$ of total precipitation (Figure 3 ).

Although stemflow represents a small portion of the total precipitation, runoff plays a more significant role in the water flow from the canopy to the roots than in tree habitats (Figure 4). In shrubs, approximately $70 \%$ of the observations indicate stemflow superior to $5 \%$, with an average of $11.1 \%( \pm 9.2 \%)$. The opposite is true for trees, as approximately $80 \%$ of the data present values below $5 \%$, with an average of $3.6 \%( \pm 3.7 \%)$. Thus, stemflow plays different roles for shrubs and trees. Although many works report morphological characteristics that could support these differences, very little has been presented to place this difference in an ecological context, even evidencing the importance of particular species for the growth in tree soil dynamics and nutrient cycling.

Some studies have proposed that precipitation intensity, number of branches (BARBIER; BALANDIER; GOSSELIN, 2009; CARLYLE-MOSES; SCHOOLING, 2015), bark texture and composition (CATINON et al., 2012; VAN STAN et al., 2016), branch and leaf saturation capacity (BARBIER; BALANDIER; GOSSELIN, 2009), and wind direction and intensity (ANDRÉ; JONARD; PONETTE, 2008) significantly influence stemflow and, consequently, the biogeochemical cycle and the ecosystems as a whole. However, few studies focus on the medium- and longterm effects of stemflow on soil dynamics and the biogeochemical cycle (LI et al., 2009; PICHLER et al., 2009).

A

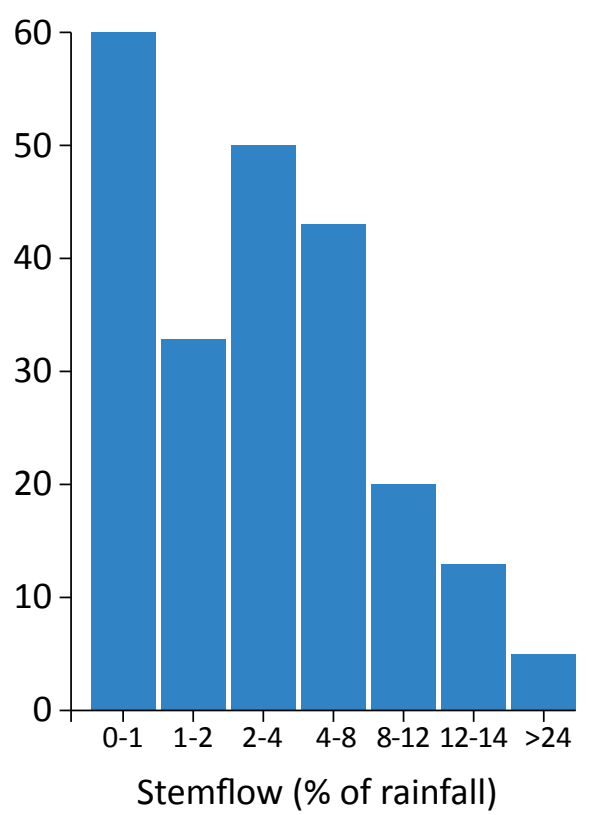

Based on the geographical coordinates of the places where the studies were performed, it was possible to map the climatic zones according to the Köppen classification (KOPPEN, 1900). Even though microclimatic and meteorological variations may affect local precipitation, temperature processes (ABREU; TONELLO, 2015; 2017; ASSIS; SOUZA; SOBRAL, 2015; BORK et al., 2017; FERNANDES; VALVERDE, 2017; SILVA; VALVERDE, 2017), and, consequently, stemflow, this climatic distribution allows a larger scale view of the observations (Figure 5).

The data show a large variation in stemflow values between climatic zones and within the same climatic zone. Climate group B (dry) has the highest mean stemflow (9.3\%). Climate groups A (tropical), C (temperate), D (continental and subarctic), and $\mathrm{E}$ (polar and alpine) present lower averages, 3.1, 2.7, 2.1, and 3.3\%, respectively. Higher runoff values may be related to climate group $\mathrm{B}$ due to its drier nature and lower rainfall indices compared to the other groups. Thus, the various plant species might have adapted to allow higher runoff generation.

When limited only to tree species, climate group B still has the highest average runoff, but with a slightly lower value $(6.0 \%)$, while the other groups show small changes in the mean $(\mathrm{A}=4.0 \%, \mathrm{C}=2.8 \%, \mathrm{D}$ $=2.4 \%$, and $\mathrm{E}=3.3 \%)$. We used the Tukey test to determine whether the differences found between the mean stemflow of the climate groups are significantly different, with $95 \%$ confidence. According to the test result considering both shrub and tree habits, the mean runoff in climate group B is significantly different from groups A ( $p<0.00001), C$ ( $\mathrm{p}<0.00001)$, and D ( $<0.04)$, but not from group E. Analyzing only tree habits, the test did not find significant differences between groups.

B

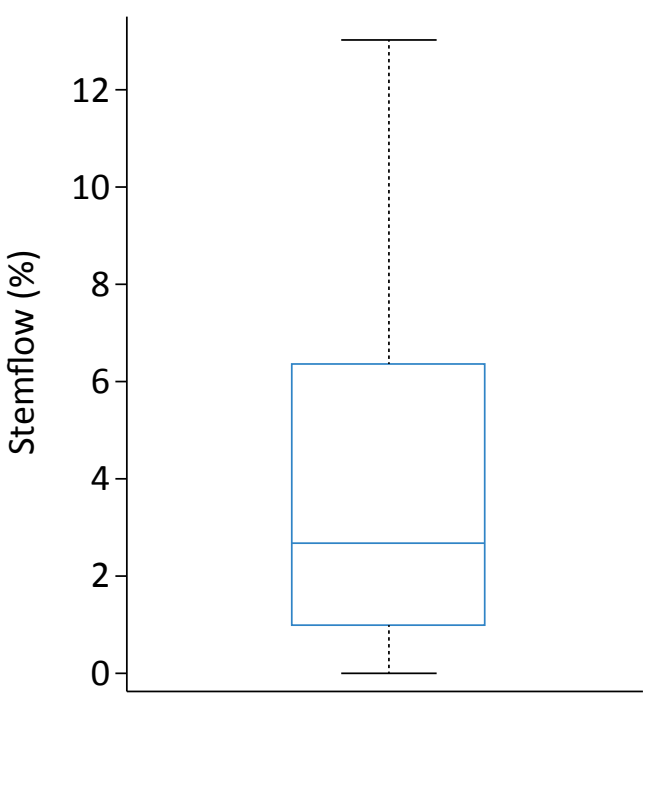

Figure 3 - (A) Number of works by stemflow class (percentage of total precipitation). (B) Distribution of stemflow values of all selected works. 
This assessment could not be performed by comparing only shrub habits since, except for group B, all groups presented insufficient data for shrubs (A and C had only one study including shrubs each, while the other groups had no studies with shrubs), at least in the data collected from the 124 survey works.

As climate group B has the most significant number of shrub runoff studies (77\%), the differences found indicate that the shrub habit is more efficient in the runoff generation, mainly due to morphological and ecological characteristics distinct from trees. However, the confirmation of this hypothesis needs to be tested with a more significant amount of data involving studies that encompass different climatic zones. At the same time, some studies point out that plants in dry environments might have adapted to channel water and nutrients in response to more severe rainfall pressures and developed mutualistic interactions, such as ecological facilitation or probiosis (FLORES; JURADO, 2003; SCHWINNING; SALA, 2004; NEWMAN et al., 2006).

In the case of groups $\mathrm{A}$ and $\mathrm{C}$, where rainfall regimes are more intense, especially in tropical regions, the abundance of rainfall water may not have been a determining factor for the adaptation of water uptake by stemflow. As a result, these regions present lower averages. Nevertheless, fewer studies have been conducted in climatic zones D and $\mathrm{E}$, and the data available may be far from representing all variations in plant species strategies. Determining these general patterns requires further investigation and studies related to the adaptations of different plant species to environmental conditions and stemflow.
Studies on the mountainous green forest and tropical forest with a high density of ectomycorrhizal trees showed that only $2 \%$ of the rain that hits the forest floor originates from stemflow, but their contribution to nutrient replacement is important (CHUYONG; NEWBERY; SONGWE, 2004; LIU; FOX; XU, 2003). Santos Terra et al. (2018) identified spatial randomness of the amount of water in the soil between different stemflow classes in an Atlantic Forest area. In other words, they report that these events are independently and evenly distributed and, therefore, likely to occur anywhere and have no interaction with each other. The authors further noted that stemflow impacted soil water content in surface layers and indicated that complex interactions between rain and forest characteristics could affect local hydrology and need to be explicitly considered in reforestation projects. Stemflow acts as an entry point since its correlations suggest the potential of using stemflow to frame soil moisture patterns and induce vertical flows as well as groundwater recharge.

The fact that soil infiltration rates decrease with increasing distance between trees should not be overlooked; thus, water is absorbed in locations closest to the tree trunk, at least in arid areas (PRESSLAND, 1976). Therefore, stemflow of a particular species and rainfall events should be considered the result of a complex set of interactions between species, plant sizes, and weather conditions, suggesting that temporal variation in forest water flow may play a significant role in subsurface drainage during rain events (LEVIA; GERMER, 2015).

In addition to abiotic factors, there is also variation in water flow according to plant species, mean stemflow measured, precipitation and

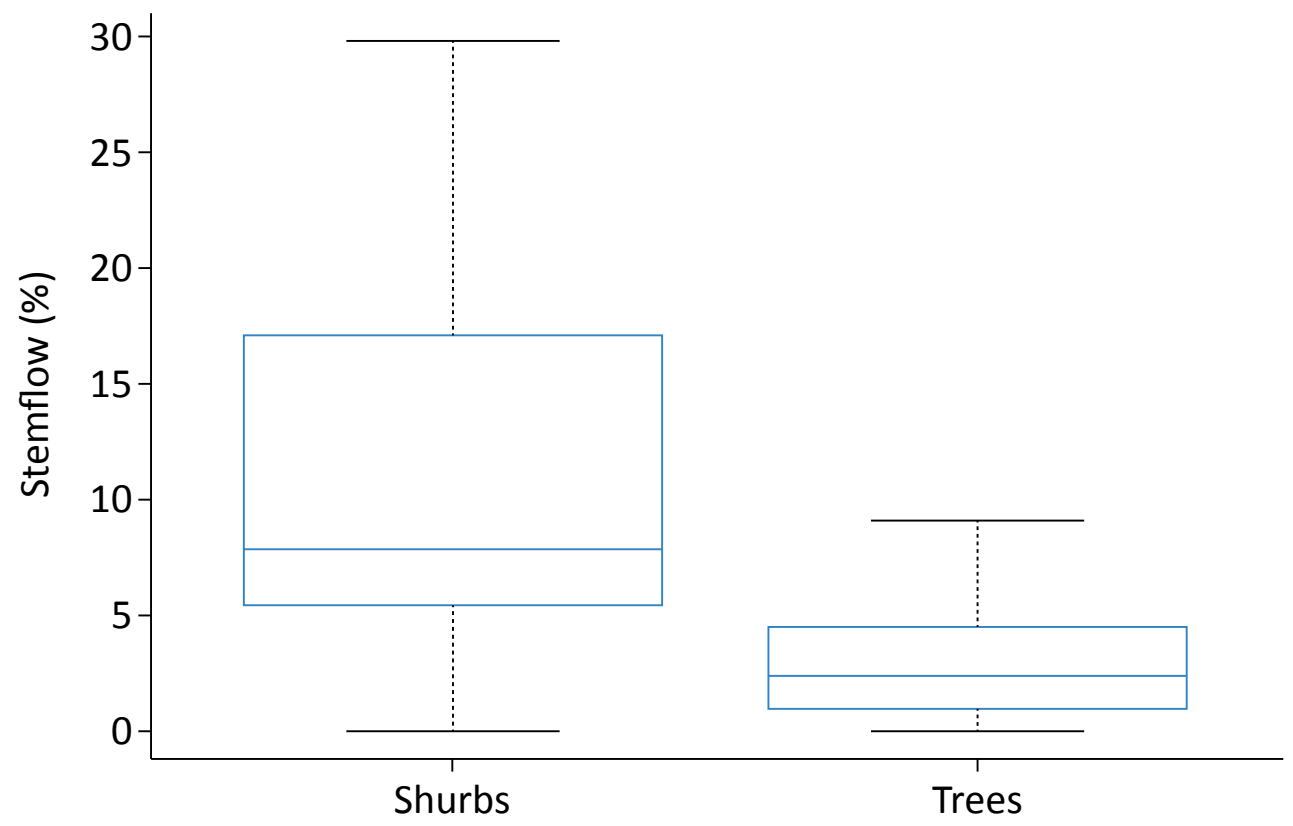

Figure 4 - Stemflow distribution values for shrub and tree habits. 
interception of two species (Grewia optiva and Morus alba), and the different contributions of each species $(2.5,86.7$, and $10.8 \%$ for G. opti$v a$ and $8.6,76.4$, and $14.7 \%$ for M. alba). The authors also reported that the nature of the tree canopy in $M$. alba resulted in a unique flow yield over G. optiva. M. alba channeled almost 3.5 times more flow than $G$. optiva, and the proportion of rain partitioning components differed for both trees due to their distinct morphological characteristics.

Recently, canopy area (or canopy volume/basal area), stem area index, and stem diameter have been identified as the most influential factors for the amount of stemflow in the Caragana korshinskii (family: Fabaceae) species (ZHANG et al., 2017). Nonetheless, it is not safe to say that the same is true for other species in the family, and few of these parameters can be adopted as part of the general stemflow pattern, although other studies have found similar results with other species (BARBIER; BALANDIER; GOSSELIN, 2009; CARLYLE-MOSES; SCHOOLING, 2015). A general pattern needs to be elaborated; however, it would require the construction of a database that includes stemflow data from different species and regions of the planet. At present, the contributions and data produced, with rare exceptions (SCHMID et al., 2011; TU et al., 2013; ZOU et al., 2015), are not readily available, so review work is a vital instrument, as it summarizes the results obtained in the area (VAN STAN; GORDON, 2018).

The funneling ratio (FR) is a characteristic that also influences stemflow. Introduced by Herwitz (1986), it quantifies the contribution of peripheral portions of a tree canopy to rain interception and stemflow generation. While stemflow represents the total flow to the ground, FR expresses the efficiency of individual trees in capturing rainwater and generating runoff. For small trees, although the volume is minimal, FR values are typically greater than those of higher trees, evidencing a competitive advantage (SIEGERT; LEVIA, 2014). A study by Raich (1983) in a mature rainforest in Costa Rica attributed high stemflow to total rainfall (9\%) to the abundance of palm trees in the area, as they are efficient at tapering stemflow (92\% of total flow).

In another study, Zimmermann et al. (2015) reported that palm trees had little influence on total stemflow, but emphasized that a closer look revealed that all monitored palm trees were relatively small, and therefore contributed only slightly higher volumes than other trees. Due to the abundance of palm trees, not only in mature open tropical forests but also in pastures and succession forests, their effects on water and nutrient cycling deserve further research (GERMER; WERTHER; ELSENBEER, 2010), as they may work as "gutters" in the interception and runoff of rainwater. Besides, some studies have shown that tree size affects the stemflow bottleneck in tropical (GERMER; WERTHER; ELSENBEER, 2010) and temperate (LEVIA et al., 2010; SIEGERT; LEVIA, 2014) forests.

Nonetheless, FR alone is not enough to explain the differences observed in water flows through the stem. For example, in the study by Yuan, Gao and Fu (2017), the percentage of total stemflow for the Caragana korshinskii species averaged 8\%, while its FR was 173.3. The

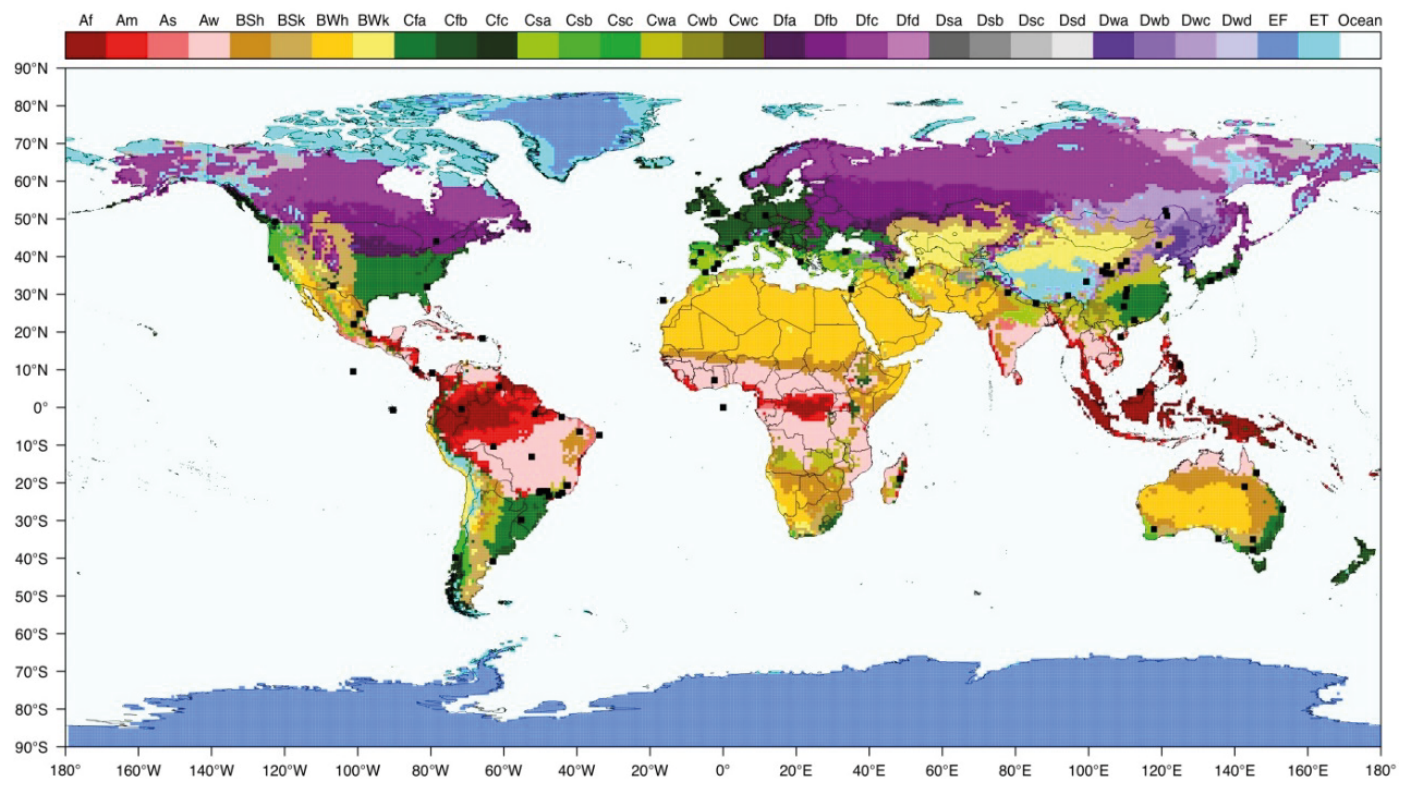

Figure 5 - Selected studies in the literature review distributed into climatic zones according to the Köppen classification. The sampled locations are represented by black dots on the map (squares).

Source: Kottek et al. (2006). 
work by Garcia-Estringana, Alonso-Blázquez and Alegre (2010) for the Cistus albidus species found an average runoff of $20.8 \%$ for an FR of 194. Several studies have reported FR values, and they vary significantly according to the species considered.

Carlyle-Moses and Price (2006) identified a range of 7 to 26 for some deciduous tree species in Canada, while Li et al. (2008) described average FR values between 24 and 153 for shrub species in semi-arid regions of China during storm events. For individual trees, FR values exceed 100 (HERWITZ, 1986), reaching 260 for Dorycnium pentaphyllum (GARCIA-ESTRINGANA; ALONSO-BLÁZQUEZ; ALEGRE, 2010) and 8 for Quercus cerris L. (CORTI et al., 2019). The linear correlation between stemflow and FR was relatively low in the selected studies (0.58). On the other hand, the amount of precipitation establishes a threshold to start the stemflow, that is, the flow varies according to the precipitation, which in turn undergoes spatial and temporal variation (YUAN; GAO; FU, 2016). Hence the difficulty in establishing a definitive stemflow contribution (Figure 6).

Several studies indicate that the stemflow contribution is around 1 to $2 \%$ of gross precipitation (AHMED et al., 2017; CHUYONG; NEWBERY; SONGWE, 2004; LIMIN et al., 2015; LORENZON; DIAS; TONELLO, 2015). Thus, Lorenzon, Dias and Tonello (2015) suggested that species with higher stemflow have some kind of morphological adaptation for rainwater harvesting. Several authors have found that understory trees produce more flow than emergent trees with a larger diameter at breast height (DBH) (LLOYD; MARQUES, 1988; NÁVAR; BRYAN, 1990; MANFROI et al., 2004). This finding shows that some species have adapted to capture rainwater through the canopy by directing it through the trunk to the roots as a way of meeting their water needs, perhaps because they depend on too much soil moisture or have shallow roots.

Various studies have sought to relate plant morphological characteristics with the stemflow yield, showing that some general correlations can be established. Yield decreases with a basal diameter of branches, while branch architecture, more abundant leaf biomass, and larger angle are more efficient for water flow production (YUAN; GAO; FU, 2016). Shinzato et al. (2011) argue that the larger the canopy size, the higher the water retention capacity and the amount of incident precipitation that will initiate the stemflow process. In addition to crown size, other authors emphasize that runoff is controlled by trunk size and shape, slope and number of branches and twigs, wooded area, and the number of leaves (LEVIA et al., 2015).

Still, according to the authors, straighter trunks with a higher number of sloping branches and fewer leaves would be more efficient in the stemflow. Therefore, the heterogeneous structural composition of the canopies is expected to exert differential effects on the stemflow yield, given the intraspecific and interspecific morphological variation found in natural environments, especially those with little anthropization.

Stemflow increases with the amount of precipitation (YUAN; GAO; FU, 2016). However, this increase is more related to the rise in rainfall and leaf area index than to the rainfall intensity (LIU et al., 2015). Levia et al. (2010) summarize that stemflow is more similar in trees of the same species than between species, with the differences being due to bark texture and water storage capacity. The authors further highlight that tree size and the characteristics of rain events affect stemflow.

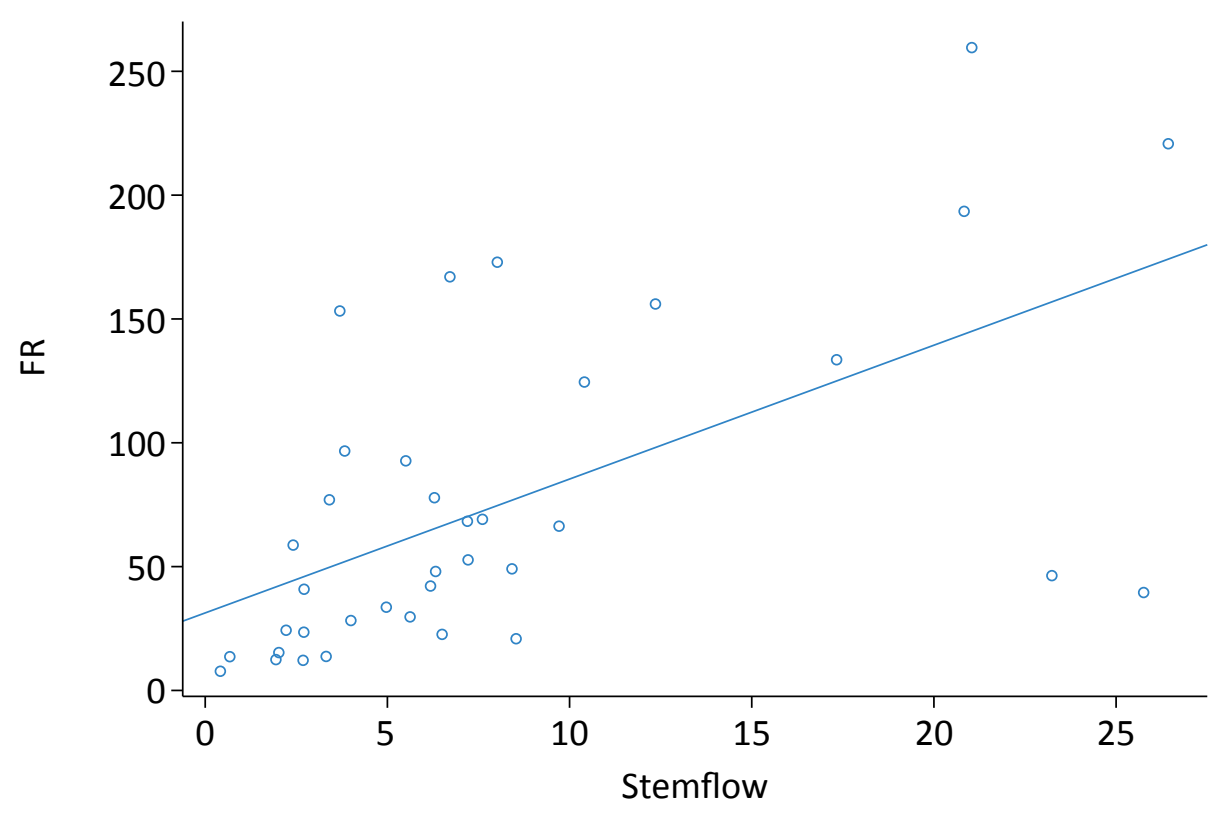

Figure 6 - Relationship between funneling ratio (FR) and stemflow efficiency (\%). 
Although many studies have considered the flow and concentration of nutrients in the stemflow, few have related its effects to the biogeochemical cycle more broadly. Consequently, further investigation on the relationship between stemflow and morphological characteristics of different species is necessary, as well as the various interactions of the biogeochemical cycle, enabling more assertive conservation and restoration actions.

Besides water, what else is in the stemflow?

Even though the stemflow contributes a small portion of the total precipitation in general, its chemical composition presents higher nutrient concentrations in relation to total precipitation and throughfall. Water and nutrient intake are influenced by vegetation type. Stemflow is fundamental for the biogeochemical balance, especially in forests with a diversity of tree species.

Schroth et al. (2001) identified phosphorus (P) and phosphate concentrations about 400 times higher in stemflow than in rainwater for Central Amazonian tree species. Liu, Fox and Xu (2003) showed that stemflow contributed about $10 \%$ of mineral nitrogen, emphasizing that this contribution should not be ignored in nutrient flow studies. At the same time, this transport is subject to several factors that can influence the concentration and flow of nutrients from the crown and stem to the soil. The volume and magnitude of rainfall, the period before rainfall, and seasonality are essential factors that can alter canopy and stem dilution and leaching processes (SIEGERT et al., 2017). Carnol and Bazgir (2013), for example, reported differences in the nutrient returned to the forest floor through litter- and throughfall under seven forest species after conversion from Norway spruce. In China, Su et al. (2019) found that mixed evergreen and deciduous broad-leaved forests present differences between mean nutrient concentrations in throughfall and stemflow. In northern temperate forests, stemflow has been extensively studied, as demonstrated by Van Stan and Gordon (2018). Brazil has some studies about the solute concentration in the hydrological process, mostly concerning monocultures (BALIEIRO et al., 2007; DICK et al., 2018; DINIZ et al., 2013; LACLAU et al., 2010).

The concentration of chemical compounds in stemflow can also be influenced by the action of organisms that live in the treetops, creating a complex network of interactions that may change the concentration of nutrients. Michalzik et al. (2016) demonstrated that under aphid (insects) infestation the water chemistry was significantly altered, showing intense $\mathrm{K}(+139 \%), \mathrm{Mg}(+82 \%), \mathrm{Mn}(+93 \%), \mathrm{S}(+$ $86 \%)$, SO4-S (+62\%), dissolved organic sulfur $(+51 \%)$, and dissolved organic nitrogen $(+62 \%)$. The authors point out that the analysis of the chemical composition can be used as a bioindicator to evaluate the impact of herbivore activity on forest ecosystems. Rosier et al. (2016) also detected variations in the composition of soil microbial communities in the stemflow of different plant species. Species-specific differences potentially change moisture, $\mathrm{pH}$, and carbon and mineral nutrient composition near the stems contributing to greater microhabitat variability.
Another critical situation was observed by Ptatscheck, Milne and Traunspurger (2018) in Germany. The authors investigated stemflow as a vector for the transport of small metazoans from tree surfaces down to the soil. The pilot study showed for the first time that stemflow is a transport vector for numerous small metazoans. They concluded that by connecting tree habitats (e.g., bark, moss, lichens, or water-filled tree holes) with soil, stemflow might influence the composition of soil fauna by mediating intensive organism dispersal. Bittar et al. (2018) also conducted an interesting study involving throughfall and stemflow from an oak-cedar forest in Southeastern USA. The authors identified that both hydrological processes were significantly enriched in bacteria compared to the open-area rainfall.

Runoff may also play a role in "discharging" large concentrations of nutrients under certain conditions. During periods of drought, chemical compounds from the atmosphere tend to accumulate in the canopy and stem. In a first precipitation event, this accumulation of chemical compounds will flow through the trunk, increasing their concentrations in relation to total precipitation and throughfall (ZHANG et al., 2016). Therefore, the transport of nutrients and other compounds from the canopy to the soil can vary significantly according to rainfall seasonality.

Stemflow has also proven to be an important factor in the transfer of anthropogenic chemical compounds to the soil and water reservoirs, as is the case with anthropogenic nitrogenous compounds (BURBANO-GARCÉS; FIGUEROA-CASAS; PEÑA, 2014). This finding raises questions about how chemicals of anthropogenic origin that are harmful to ecosystems are being incorporated into the biogeochemical cycle, especially inert compounds such as hydrochlorofluorocarbons (HCFCs).

A study by Glinski et al. (2018) investigated the cumulative effect of 160 pesticides on the environment and measured the concentrations of these compounds in stemflow. The authors found similar concentrations of herbicides, fungicides, and insecticides on the surface of water bodies and stemflow, revealing the importance and indirect impact of the exposure of these environments to chemical agents of anthropic origin. Two years after the nuclear accident at the power plant in Fukushima, Japan, Endo et al. (2015) measured the radioactive cesium concentration (137Cs) on throughfall and stemflow. The authors pointed out that due to the defoliation caused by radioactivity in the area, the flow was significantly high, transporting $137 \mathrm{Cs}$ to the soil.

Therefore, stemflow and throughfall play a dominant role in biogeochemical processes through the nutrient flow of compounds deposited in the canopy, especially after long periods of drought, and their contribution can account for up to $50 \%$ of the total nutrients returned to the soil (HOFHANSL et al., 2012). Like the flow of water, the chemical composition is influenced not only by environmental characteristics but also by plant species, their interactions with other organisms, and their localized effects; their contribution may not be detected, but they are certainly important to ecosystems (GERMER et al., 2012). 


\section{Final Considerations}

The growing number of studies on the subject in the most diverse regions, especially in the last two decades, has contributed to answering several questions about the importance and role of stemflow in ecosystems and the biogeochemical cycle. However, new questions arise as our knowledge of the topic deepens, revealing not only its complexity but also its diversity. Future works should seek to explore multidisciplinary aspects involving biotic and abiotic components and the impact of their interactions, seeking to quantify stemflow concerning plant morphological, physiological, and biochemical characteristics, as well as qualify the flow outcome in spatial and temporal scales.

With the stemflow contribution to the input of nutrients and microorganisms in the soil, would it be better to explore this relationship as a function of forest species in recognized diversity biomes? We believe that linking stemflow and soil recovery is necessary. Perhaps we could identify species with higher nutrient inputs to the soil and eventually explore them, positively, for the recovery of degraded soils, especially when it comes to forest restoration.

\section{Contribution of authors:}

Tonello, K.C.: Project administration, Supervision, Conceptualization, Review \& editing. Balbinot, L.: Investigation, Formal analysis, Data curation, Writing First draft; Pereira, L.C.: Investigation, Formal analysis. Matus, G.N.: Investigation, Formal analysis. Lima, M.T.: Investigation, Formal analysis.

\section{References}

ABREU, M.C.; TONELLO, K.C. Avaliação dos Parâmetros

Hidrometeorológicos na Bacia do Rio Sorocaba/SP. Revista Brasileira de Meteorologia, v. 32, n. 1, p. 99-109, 2017. https://doi.org/10.1590/0102778632120150164

ABREU, M.C.; TONELLO, K.C. Estimativa do balanço hídrico climatológico da bacia hidrográfica do rio Sorocaba - São Paulo. Ambiência, Guarapuava, v. 11, n. 3, p. 513-527, 2015. http://doi.org/10.5935/ambiencia.2015.03.01

AHMED, A.; TOMAR, J.M.S.; MEHTA, H.; KAUSHAL, R.; DEB, D.; CHATURVEDI, O.P.; MISHRA, P.K. Throughfall, stemflow and interception loss in grewia optiva and morus alba in North West Himalayas. Tropical Ecology, v. 58, n. 3, p. 507-514, 2017.

ANDRÉ, F.; JONARD, M.; PONETTE, Q. Spatial and temporal patterns of throughfall chemistry within a temperate mixed oak-beech stand. Science of the Total Environment, v. 397, n. 1-3, p. 215-228, 2008. https://doi. org/10.1016/j.scitotenv.2008.02.043

ASSIS, J.; SOUZA, W.; SOBRAL, M. do C. Análise climática da precipitação no submédio da bacia do rio São Francisco com base no índice de anomalia de chuva. Revista Brasileira de Ciências Ambientais (Online), n. 36, p. 115-127, 2015. https://doi.org/10.5327/Z2176-947820151012

BALIEIRO, F.D.C.; FRANCO, A.A.; FONTES, R.L.F.; DIAS, L.E.; CAMPELLO, E.F.C.; FARIA, S.M. Evaluation of the throughfall and stemflow nutrient contents in mixed and pure plantations of Acacia mangium, Pseudosamenea guachapele and Eucalyptus grandis. Revista Árvore, v. 31, n. 2, p. 339-346, 2007. https://doi.org/10.1590/S0100-67622007000200017

BARBIER, S.; BALANDIER, P.; GOSSELIN, F. Influence of several tree traits on rainfall partitioning in temperate and boreal forests: a review. Annals of Forest Science, v. 66, p. 602, 2009. https://doi.org/10.1051/ forest/2009041

BESSI, D.; DIAS, H.C.T.; TONELLO, K.C. Rainfall Partitioning in fragments of Cerrado vegetation at different stages of conduction of natural regeneration. Revista Árvore, Viçosa, v. 42, n. 2, 2018a. http://dx.doi. org/10.1590/1806-90882018000200015
BESSI, D.; TANAKA, M.O.; COSTA, L.A.; CORREA, C.J.P; TONELLO, K.C. Forest restoration and hydrological parameters effects on soil water conditions: a structural equation modelling approach. Revista Brasileira de Recursos Hídricos, Porto Alegre, v. 23, 2018b. http://dx.doi.org/10.1590/23180331.231820180043

BIDDICK, M.; HUTTON, I.; BURNS, K.C. An alternative water transport system in land plants. Proceedings of the Royal Society B: Biological Sciences, v. 285, n. 1884, p. 3-5, 2018. https://doi.org/10.1098/rspb.2018.0995

BITTAR, T.B.; POUND, P.; WHITETREE, A.; MOORE, L.D.; VAN STAN, J.T. Estimation of Throughfall and Stemflow Bacterial Flux in a Subtropical Oak-Cedar Forest. Geophysical Research Letters, v. 45, n. 3, p. 1410-1418, 2018. https://doi.org/10.1002/2017GL075827

BIVAND, R.; RUNDEL, C. Rgeos: Interface to Geometry Engine - Open Source ('GEOS'). R package version 0.4-2. 2018. Available at: $<$ https://CRAN. Rproject.org/package $=$ rgeos $>$. Accessed on: Oct. 28, 2019.

BORK, C.; CASTRO, A.; LEANDRO, D.; CORRÊA, L., SIQUEIRA, T. Índices de precipitação extrema para os períodos atual (1961-1990) e futuro (2011-2100) na bacia do rio Taquari-Antas, RS. Revista Brasileira de Ciências Ambientais (Online), n. 46, p. 29-45, 2017. https://doi.org/10.5327/Z2176-947820170233

BRANCALION, P.H.S.; VIANI, R.A.G.; RODRIGUES, R.R.; GANDOLFI, S. Avaliação e monitoramento de áreas em processo de restauração. In: MARTINS, S. V. (ed.). Restauração Ecológica de Ecossistemas Degradados. Viçosa: Editora UFV, 2012. p. 262-293.

BURBANO-GARCÉS, M.; FIGUEROA-CASAS, A.; PEÑA, M. Bulk precipitation, throughfall and stemflow deposition of n-nh4 +, n-nh3 and n-no3 - in an Andean forest. Journal of Tropical Forest Science, v. 26, n. 4, p. 446-457, 2014

CARLYLE-MOSES, D.E.; PRICE, A.G. Growing-season stemflow production within a deciduous forest of southern Ontario. Hydrological Processes, v. 20, p. 3651-3663, 2006. https://doi.org/10.1002/hyp.6380

CARLYLE-MOSES, D.E.; SCHOOLING, J.T. Tree traits and meteorological factors influencing the initiation and rate of stemflow from isolated deciduous 
trees. Hydrological Processes, v. 29, n. 18, p. 4083-4099, 2015. https://doi. org/10.1002/hyp.10519

CARNOL, M.; BAZGIR, M. Nutrient return to the forest floor through litter and throughfall under 7 forest species after conversion from Norway spruce. Forest Ecology and Management, v. 309, p. 66-75, 2013. https://doi.org/10.1016/j. foreco.2013.04.008

CATINON, M.; AYRAULT, S.; BOUDOUMA, O.; ASTA, J.; TISSUT, M.; RAVANEL, P. Atmospheric element deposit on tree barks: The opposite effects of rain and transpiration. Ecological Indicators, v. 14, n. 1, p. 170-177, 2012 https://doi.org/10.1016/j.ecolind.2011.07.013

CAYUELA, C.; LLORENS, P.; SÁNCHEZ-COSTA, E.; LEVIA, D.F.; LATRON, J. Effect of biotic and abiotic factors on inter- and intra-event variability in stemflow rates in oak and pine stands in a Mediterranean mountain area. Journal of Hydrology, v. 560, p. 396-406, 2018. https://doi.org/10.1016/j. jhydrol.2018.03.050

CHUYONG, G.B.; NEWBERY, D.M.; SONGWE, N.C. Rainfall input, throughfall and stemflow of nutrients in a central African rain forest dominated by ectomycorrhizal trees. Biogeochemistry, v. 67, p. 73-91, 2004. https://doi.org/10.1023/B:BIOG.0000015316.90198.cf

CORTI, G.; AGNELLI, A.; COCCO, S.; CARDELLI, V.; MASSE, J.; COURCHESNE, F. Soil affects throughfall and stemflow under Turkey oak (Quercus cerris L.). Geoderma, v. 333, p. 43-56, 2019. https://doi.org/10.1016/j. geoderma.2018.07.010

DICK, G.; SCHUMACHER, M.V.; MOMOLLI, D.R.; VIERA, M. Nutrient Input via Incident Rainfall in a Eucalyptus dunnii Stand in the Pampa biome. Floresta e Ambiente, v. 25, n. 3, p. 1-9, 2018. https://doi.org/10.1590/21798087.055916

DINIZ, A.R.; PEREIRA, M.G.; BALIEIRO, F.D.C.; MACHADO, D.L.; MENEZES, C.E.G. Precipitação e aporte de nutrientes em diferentes estádios sucessionais de floresta Atlântica, Pinheiral - RJ. Ciência Florestal, v. 23, n. 3, p. 389-399, 2013. http://dx.doi.org/10.5902/1980509810550

ELSEVIER B.V. Scopus. 2019. Available at: <https://www.scopus.com>. Accessed on: Dec. 1, 2019.

ENDO, I.; OHTE, N.; ISEDA, K.; TANOI, K.; HIROSE, A.; KOBAYASHI, N.I.; MURAKAMI, M.; TOKUCHI, N.; OHASHI, M. Estimation of radioactive 137-cesium transportation by litterfall, stemflow and throughfall in the forests of Fukushima. Journal of Environmental Radioactivity, v. 149, p. 176-185, 2015 https://doi.org/10.1016/j.jenvrad.2015.07.027

FERNANDES, R.; VALVERDE, M. Análise da resiliência aos extremos climáticos de chuva: estudo preliminar na região de Mauá no ABC paulista São Paulo. Revista Brasileira de Ciências Ambientais (Online), n. 44, p. 1-17, 2017. https://doi.org/10.5327/Z2176-947820170183

FLORES, J.; JURADO, E. Are nurse-protégé interactions more common among plantsfrom arid environments. Journal of Vegetation Science, v. 14, n. 6, p. $911-916,2003$.

GALETTI, G.; SILVA, J.; PIÑA-RODRIGUES, F.; PIOTROWISKI, I. Análise multicriterial da estabilidade ecológica em três modelos de restauração florestal. Revista Brasileira de Ciências Ambientais (Online), n. 48, p. 142-157, 2018. https://doi.org/10.5327/Z2176-947820180301

GARCIA-ESTRINGANA, P.; ALONSO-BLÁZQUEZ, N.; ALEGRE, J. Water storage capacity, stemflow and water funneling in Mediterranean shrubs. Journal of Hydrology, v. 389, n. 3-4, p. 363-372, 2010. https://doi.org/10.1016/j. jhydrol.2010.06.017

GERMER, S.; WERTHER, L.; ELSENBEER, H. Have we underestimated stemflow? Lessons from an open tropical rainforest. Journal of Hydrology, v. 395, n. 3-4, p. 169-179, 2010. https://doi.org/10.1016/j.jhydrol.2010.10.022
GERMER, S.; ZIMMERMANN, A.; NEILL, C.; KRUSCHE, A. V.; ELSENBEER, H. Disproportionate single-species contribution to canopy-soil nutrient flux in an Amazonian rainforest. Forest Ecology and Management, v. 267, p. 40-49, 2012. https://doi.org/10.1016/j.foreco.2011.11.041

GLINSKI, D.A.; PURUCKER, S.T.; VAN METER, R.J.; BLACK, M.C.; HENDERSON, W.M. Analysis of pesticides in surface water, stemflow, and throughfall in an agricultural area in South Georgia, USA. Chemosphere, v. 209, p. 496-507, 2018. https://doi.org/10.1016/j.chemosphere.2018.06.116

GUIDELLI, A. Dados de escoamento pelo tronco obtidos a partir da revisão da literatura do período 2006 a 2019. 2019. Available at: <https://figshare.com/ articles/revisao-dadosxlsx/7770824>. Accessed on: May 21, 2020.

HERWITZ, S.R. Infiltration-excess caused by Stemflow in a cyclone-prone tropical rainforest. Earth Surface Processes and Landforms, v. 11, n. 4, p. 401 412, 1986. https://doi.org/10.1002/esp.3290110406

HIJMANS, R.J. Raster: geographic data analysis and modeling. R package version 2.8-4. 2018. Available at: <https:/CRAN.R-project.org/ package $=$ raster $>$. Accessed on: Aug. 30, 2019.

HOFHANSL, F.; WANEK, W.; DRAGE, S.; HUBER, W.; WEISSENHOFER, A.; RICHTER, A. Controls of hydrochemical fluxes via stemflow in tropical lowland rainforests: Effects of meteorology and vegetation characteristics. Journal of Hydrology, v. 452-453, p. 247-258, 2012. https://doi.org/10.1016/j. jhydrol.2012.05.057

KOPPEN, W. Attempting to classify the climates preferably according to their relationship to the plant world. Geographische Zeitschrift, v. 6, p. 593-611, 1900. Available at: <https://upload.wikimedia.org/wikipedia/commons/d/df/ Versuch_einer_Klassifikation_der_Klimate\%2C_vorzugsweise_nach_ihren_ Beziehungen_zur_Pflanzenwelt_Schluss_\%281900\%29.pdf>. Accessed on: Dec. 10, 2018.

KOTTEK, M.; GRIESER, J.; BECK, C.; RUDOLF, B.; RUBEL, F. World Map of the Köppen-Geiger climate classification updated. Meteorologische Zeitschrift, v. 15 , n. 3, p. 259-263, 2006. https://doi.org/10.1127/0941-2948/2006/0130

LACLAU, J.-P.; RANGER, J.; MORAES GONÇALVES, J.L.; MAQUÈRE, V.; KRUSCHE, A.V.; M’BOU, A.T.; NOUVELLON, Y.; SAINT-ANDRÉ, L.; BOUILLET, J.-P.; CASSIA PICCOLO, M.; DELEPORTE, P. Biogeochemical cycles of nutrients in tropical Eucalyptus plantations. Forest Ecology and Management, v. 259, n. 9, p. 1771-1785, 2010. https://doi.org/10.1016/j.foreco.2009.06.010

LEVIA, D.F.; GERMER, S. A review of stemflow generation dynamics and stemflow-environment interactions in forests and shrublands. Reviews of Geophysics, v. 53, n. 3, p. 673-714, 2015. https://doi.org/10.1002/ 2015RG000479

LEVIA, D.F; MICHALZIK, B.; BISCHOFF, S.; NÄTHE, K.; LEGATES, D.R.; GRUSELLE, M.C.; RICHTER, S. Measurement and modeling of diameter distributions of particulate matter in terrestrial solutions. Geophysical Research Letters, v. 40, n. 7, p. 1317-1321, 2013. https://doi.org/10.1002/grl.50305

LEVIA, D.F.; MICHALZIK, B.; NÄTHE, K.; BISCHOFF, S.; RICHTER, S.; LEGATES, D.R. Differential stemflow yield from European beech saplings: the role of individual canopy structure metrics. Hydrological Processes, v. 29, n. 1, p. 43-51, 2015. https://doi.org/10.1002/hyp.10124

LEVIA, D.F.; VAN STAN, J.T.; MAGE, S.M.; KELLEY-HAUSKE, P.W. Temporal variability of stemflow volume in a beech-yellow poplar forest in relation to tree species and size. Journal of Hydrology, v. 380, n. 1-2, p. 112-120, 2010. https://doi.org/10.1016/j.jhydrol.2009.10.028

LI, X.-Y.; LIU, L.Y.; GAO, S.Y.; MA, Y.J.; YANG, Z.P. Stemflow in three shrubs and its effect on soil water enhancement in semiarid loess region of China. Agricultural and Forest Meteorology, v. 148, n. 10, p. 1501-1507, 2008. https:// doi.org/10.1016/j.agrformet.2008.05.003 
LI, X.-Y.; YANG, Z.-P.; LI, Y.-T.; LIN, H. Connecting ecohydrology and hydropedology in desert shrubs: stemflow as a source of preferential flow in soils. Hydrology and Earth System Sciences, v. 13, p. 1133-1144, 2009. https:// doi.org/10.5194/hessd-6-1551-2009

LIMIN, S.G.; OUE, H.; SATO, Y.; BUDIASA, I.W.; SETIAWAN, B.I. Partitioning Rainfall into Throughfall, Stemflow, and Interception Loss in Clove (Syzygium Aromaticum) Plantation in Upstream Saba River Basin, Bali. Procedia Environmental Sciences, v. 28, p. 280-285, 2015. https://doi. org/10.1016/j.proenv.2015.07.036

LIU, H.; ZHANG, R.; ZHANG, L.; WANG, X.; LI, Y.; HUANG, G. Stemflow of water on maize and its influencing factors. Agricultural Water Management, $\mathrm{v}$. 158, p. 35-41, 2015. https://doi.org/10.1016/j.agwat.2015.04.013

LIU, W.; FOX, J.E.D.; XU, Z. Nutrient budget of a montane evergreen broadleaved forest at Ailao Mountain National Nature Reserve, Yunnan, southwest China. Hydrological Processes, v. 17, n. 6, p. 1119-1134, 2003. https://doi. org/10.1002/hyp.1184

LLOYD, C.R.; O. MARQUES, A.O. Spatial variability of throughfall and stemflow measurements in Amazonian rainforest. Agricultural and Forest Meteorology, v. 42, n. 1, p. 63-73, 1988. https://doi.org/10.1016/01681923(88)90067-6

LORENZON, A.S.; DIAS, H.C.T.; TONELLO, K.C. Escoamento da água da chuva pelo tronco das árvores em uma floresta estacional semidecidual. Revista Árvore, v. 39, n. 3, p. 423-430, 2015. http://dx.doi.org/10.1590/010067622015000300002

MANFROI, O.J.; KOICHIRO, K.; NOBUAKI, T.; MASAKAZU, S.; NAKAGAWA, M.; NAKASHIZUKA, T.; CHONG, L. The stemflow of trees in a Bornean lowland tropical forest. Hydrological Processes, v. 18, n. 13, p. 24552474, 2004. https://doi.org/10.1002/hyp.1474

MCKEE, A.J.; CARLYLE-MOSES, D.E. Modelling stemflow production by juvenile lodgepole pine (Pinus contorta var. latifolia) trees. Journal of Forestry Research, v. 28, p. 565-576, May 2017. https://doi.org/10.1007/s11676-0160336-9

MICHALZIK, B.; LEVIA, D.F.; BISCHOFF, S.; NÄTHE, K.; RICHTER, S. Effects of aphid infestation on the biogeochemistry of the water routed through European beech (Fagus sylvatica L.) saplings. Biogeochemistry, v. 129, p. 197-214, Aug. 2016. https://doi.org/10.1007/s10533-016-0228-2

NÁVAR, J.; BRYAN, R. Interception loss and rainfall redistribution by three semi-arid growing shrubs in northeastern Mexico. Journal of Hydrology, v. 115, n. 1-4, p. 51-53, 1990. https://doi.org/10.1016/0022-1694(90)90197-6

NEWMAN, B.D.; WILCOX, B.P.; ARCHER, S.R.; BRESHEARS, D.D.; DAHM, C.N.; DUFFY, C.J.; MCDOWELL, N.G.; PHILLIPS, F.M.; SCANLON, B.R.; VIVONI, E.R. Ecohydrology of water-limited environments: a scientific vision. Water Resources Research, v. 42, n. 6, 2006. https://doi. org/10.1029/2005WR004141

OLIVEIRA JÚNIOR, J.C.; DIAS, H.C.T. Precipitação efetiva em fragmento secundário da mata atlântica. Revista Árvore, v. 29, n. 1, p. 9-15, 2005. https:// doi.org/10.1590/S0100-67622005000100002

PICHLER, V.; GREGOR, J.; HOMOLÁK, M.; CAPULIAK, J.; BEBEJ, J.; VÁL'KA, J. Prediction of medium- and long-term changes in soil reaction in a beech forest based on observations in the beech stemflow zone. Folia Oecologica, v. 34, n. 2, p. 146-152, 2007.

PRESSLAND, A. Soil Moisture Redistribution as Affected by Throughfall and Stemflow in an Arid Zone Shrub Community. Australian Journal of Botany, v. 24, n. 5, p. 641-649, 1976.
PTATSCHECK, C.; MILNE, P.C.; TRAUNSPURGER, W. Is stemflow a vector for the transport of small metazoans from tree surfaces down to soil? $B M C$ Ecology, v. 18, 2018. https://doi.org/10.1186/s12898-018-0198-4

RAICH, J. W. Understory palms as nutrient traps: A hypothesis. Brenesia, n. 21, p. 119-129, 1983.

R CORE TEAM. R: A Language and Environment for Statistical Computing. Vienna, 2018. Available at: <https://www.R-project.org >. Accessed on: Aug. 15, 2018.

ROCHA-URIARTT, L.; CASSANEGO, M.; BECKER, D.; DROSTE, A.; SCHMITT, J. Diagnóstico ambiental de mata ciliar: uma análise integrada de parâmetros botânicos, meteorológicos e da genotoxicidade do ar atmosférico. Revista Brasileira de Ciências Ambientais (Online), n. 35, p. 102-115, 2015.

RODRIGUES, R. R.; BRANCALION, P. H. S.; ISERNHAGEN, I. Pacto pela restauração da mata atlântica: referencial dos conceitos e ações de restauração florestal (LERF/ESALQ). São Paulo: Instituto BioAtlântica, 2009.

ROSIER, C.L.; LEVIA, D.F.; VAN STAN, J.T.; AUFDENKAMPE, A.; KAN, J. Seasonal dynamics of the soil microbial community structure within the proximal area of tree boles: Possible influence of stemflow. European Journal of Soil Biology, v. 73, p. 108-118, 2016. https://doi.org/10.1016/j.ejsobi.2016.02.003

SANTOS TERRA, M.C.N.; MELLO, C.R.; MELLO, J.M.; OLIVEIRA, V.A.; NUNES, M.H.; SILVA, V.O.; RODRIGUES, A.F.; ALVES, G.J. Stemflow in a neotropical forest remnant: vegetative determinants, spatial distribution and correlation with soil moisture. Trees - Structure and Function, v. 32, p. 323-335, 2018. https://doi.org/10.1007/s00468-017-1634-3

SCHMID, S.; BURKARD, R.; FRUMAU, K.F.A.; TOBÓN, C.; BRUIJNZEEL, L.A.; SIEGWOLF, R.; EUGSTER, W. Using eddy covariance and stable isotope mass balance techniques to estimate fog water contributions to a Costa Rican cloud forest during the dry season. Hydrological Processes, v. 25, n. 3, p. 429437, 2011. https://doi.org/10.1002/hyp.7739

SCHROTH, G.; ELIAS, M.E.A.; UGUEN, K.; SEIXAS, R.; ZECH, W. Nutrient fluxes in rainfall, throughfall and stemflow in tree-based land use systems and spontaneous tree vegetation of central Amazonia. Agriculture, Ecosystems and Environment, v. 87, n. 1, p. 37-49, 2001. https://doi.org/10.1016/S01678809(00)00294-2

SCHWINNING, S.; SALA, O.E. Hierarchy of responses to resource pulses in arid and semi-arid ecosystems. Oecologia, v. 141, p. 211-220, 2004. https://doi. org/10.1007/s00442-004-1520-8

SCIELO. SciELO: Scientific Electronic Library Online. 2019.

SHINZATO, E.T.; TONELLO, K.C.; GASPAROTO, E.A.G.; VALENTE, R.O.A. Stemflow in different forest fragments of Ipanema National Forest in Iperó, Brazil. Scientia Forestalis/Forest Sciences, v. 39, n. 92, p. 395-402, 2011. https:// doi.org/10.13140/2.1.3996.2242

SIEGERT, C.M.; LEVIA, D.F. Seasonal and meteorological effects on differential stemflow funneling ratios for two deciduous tree species. Journal of Hydrology, v. 519, parte A, p. 446-454, 2014. https://doi.org/10.1016/j. jhydrol.2014.07.038

SIEGERT, C.M.; LEVIA, D.F.; LEATHERS, D.J.; VAN STAN, J.T.; MITCHELL, M.J. Do storm syn- optic patterns affect biogeochemical fluxes from temperate deciduous forest canopies? Biogeochemistry, v. 132, p. 273-292, 2017. https:// doi.org/10.1007/s10533-017-0300-6

SILVA, M.C.; VALVERDE, M. Cenário futuro da disponibilidade hídrica na bacia do Alto Tietê. Revista Brasileira de Ciências Ambientais (Online), n. 43, p. 114-130, 2017. https://doi.org/10.5327/Z2176-947820170185

SOCIETY FOR ECOLOGICAL RESTORATION INTERNATIONAL. The SER International Primer on Ecological Restoration. Tucson: Society for Ecological Restoration International, 2004. Available at: <https://cdn.ymaws.com/www. 
ser.org/resource/resmgr/custompages/publications/ser_publications/ser primer.pdf $>$. Accessed on: May 23, 2017.

SOUZA, H.; VITORINO, M. I.; VASCONCELOS, S.; MARINHO, E.; BISPO, C. J. Influência de sistemas precipitantes sobre a produção de serapilheira em manguezal da costa amazônica. Revista Brasileira de Ciências Ambientais (Online), n. 54, p. 105-118, 30 dez. 2019. https://doi.org/10.5327/Z2176947820190571

SPENCER, S.A.; VAN MEERVELD, H.J. Double funnelling in a mature coastal British Columbia forest: spatial patterns of stemflow after infiltration. Hydrological Processes, v. 30, n. 22, p. 4185-4201, 2016. https://doi.org/10.1002/ hyp. 10936

SU, L.; ZHAO, C.; XU, W.; XIE, Z. Hydrochemical Fluxes in Bulk Precipitation, Throughfall, and Stemflow in a Mixed Evergreen and Deciduous Broadleaved Forest. Forests, v. 10, n. 6, p. 507, 2019. https://doi. org/10.3390/f10060507

TANAKA, N.; LEVIA, D.; IGARASHI, Y.; YOSHIFUII, N.; TANAKA, K.; TANTASIRIN, C.; NANKO, K.; SUZUKI, M.; KUMAGAI, T. What factors are most influential in governing stemflow production from plantationgrown teak trees? Journal of Hydrology, v. 544, p. 10-20, 2017. https://doi. org/10.1016/j.jhydrol.2016.11.010

TU, L.; HU, H.; ZHANG, J.; HUANG, L.; XIAO, Y.; CHEN, G.; HU, H.L.; LIU, L.; ZHENG, J.; XU, Z.; CHEN, L. Nitrogen Distribution and Cycling through Water Flows in a Subtropical Bamboo Forest under High Level of Atmospheric Deposition. PLoS One, v. 8, n. 10, p. 2-12, 2013. https://doi.org/10.1371/ journal.pone.0075862

VAN STAN, J.T.; GORDON, D.A. Mini-Review: Stemflow as a Resource Limitation to Near-Stem Soils. Frontiers in Plant Science, v. 9, p. 248, 2018. https://doi.org/10.3389/fpls.2018.00248
VAN STAN, J.T.; LEWIS, E.S.; HILDEBRANDT, A.; REBMANN, C.; FRIESEN, J. Impact of interacting bark structure and rainfall conditions on stemflow variability in a temperate beech-oak forest, central Germany. Hydrological Sciences Journal, v. 61, n. 11, p. 2071-2083, 2016. https://doi.org/10.1080/02626 667.2015.1083104

YUAN, C.; GAO, G.; FU, B. Comparisons of stemflow and its bio-/abiotic influential factors between two xerophytic shrub species. Hydrology and Earth System Sciences, v. 21, p. 1421-1438, 2017. https://doi.org/10.5194/hess-211421-2017

YUAN, C.; GAO, G.; FU, B. Stemflow of a xerophytic shrub (Salix psammophila) in northern China: Implication for beneficial branch architecture to produce stemflow. Journal of Hydrology, v. 539, p. 577-588, 2016. https://doi.org/10.1016/j.jhydrol.2016.05.055

ZHANG, Y.W.; DENG, L.; YAN, W.M.; SHANGGUAN, Z.P. Interaction of soil water storage dynamics and long-term natural vegetation succession on the Loess Plateau, China. Catena, v. 137, p. 52-60, 2016. https://doi.org/10.1016/j. catena.2015.08.016

ZHANG, Y.W.; WANG, X.; HU, R.; PAN, Y.X. Stemflow volume per unit rainfall as a good variable to determine the relationship between stemflow amount and morphological metrics of shrubs. Journal of Arid Environments, v. 141, p. 1-6, 2017. https://doi.org/10.1016/j. jaridenv.2017.02.002

ZIMMERMANN, A.; UBER, M.; ZIMMERMANN, B.; LEVIA, D.F. Predictability of stemflow in a species-rich tropical forest. Hydrological Processes, v. 29, n. 23, p. 4947-4956, 2015. https://doi.org/10.1002/hyp.10554

ZOU, C.B.; CATERINA, G.L.; WILL, R.E.; STEBLER, E.; TURTON, D. Canopy interception for a tallgrass prairie under juniper encroachment. PLoS One, v. 10, n. 11, p. 1-19, 2015. https://doi.org/10.1371/journal.pone.0141422 